Anna Tomaka-Magdoñ ${ }^{1}$

\title{
Decyzje Urzędu Patentowego w postępowaniu 0 udzielenie prawa ochronnego na znak towarowy
}

\section{Wprowadzenie}

Znak towarowy, często określany też jako marka, jest uważany za jeden z najważniejszych, najwartościowszych elementów przedsiębiorstwa. Znaki towarowe - marki, które odniosły sukces, gdyż klienci przywiązali się do oznaczenia, stając się konsumentami produktów oznaczonych tymi znakami, przynoszą tym samym wymierne zyski. Takie znaki są też obiektem zainteresowania konkurentów, którzy w sposób nieuczciwy próbują wykorzystać popularność oznaczeń znanych i renomowanych. Dlatego ważne dla przedsiębiorcy jest zabezpieczenie swoich praw i uzyskanie wyłączności na dany znak poprzez jego zarejestrowanie.

W 2015 r. nastąpiły istotne zmiany w systemie ochrony własności przemysłowej w Polsce. Sejm RP przyjął trzy ustawy wprowadzające te zmiany: ustawę z dnia 24 lipca 2015 r. o zmianie ustawy - Prawo własności przemysłowej i niektórych innych ustaw (Dz. U. poz. 1266), ustawę z dnia 5 sierpnia 2015 r. o zmianie ustaw regulujących warunki dostępu do wykonywania niektórych zawodów (Dz. U. poz. 1505) oraz ustawę z dnia 11 września 2015 r. o zmianie ustawy - Prawo własności przemysłowej (Dz. U. poz. 1615).

Celem pierwszej nowelizacji było dostosowanie ustawodawstwa polskiego do uregulowań międzynarodowych, jak Akt genewski Porozumienia haskiego w sprawie międzynarodowej rejestracji wzorów przemysłowych, przyjęty w Genewie 2 lipca 1999 r. czy Traktat singapurski o prawie znaków towarowych i regulamin do Traktatu singapurskiego o prawie znaków towarowych, przyjęte w Singapurze 27 marca 2006 r.

Kolejna nowelizacja przełamuje monopol rzeczników patentowych, gdyż od 30 listopada 2015 r. pełnomocnikiem strony w postępowaniu przed Urzędem Patentowym RP w sprawach związanych z dokonywaniem i rozpatrywaniem zgłoszeń oraz utrzymywaniem ochrony znaków towarowych może być nie tylko rzecznik patentowy, ale także radca prawny, adwokat

1 Anna Tomaka-Magdoń, starszy asystent sędziego w Naczelnym Sądzie Administracyjnym. 
lub osoba świadcząca usługi transgraniczne w rozumieniu ustawy o rzecznikach patentowych. Monopol rzecznika został utrzymany jednak w sprawach związanych $\mathrm{z}$ dokonywaniem i rozpatrywaniem zgłoszeń oraz utrzymywaniem ochrony wynalazków, produktów leczniczych oraz produktów ochrony roślin, wzorów użytkowych, wzorów przemysłowych, oznaczeń geograficznych i topografii układów scalonych.

Istotna nowość dotyczy procedury uzyskania praw ochronnych na znaki towarowe, wprowadzonej nowelą z dnia 11 września 2015 r., która weszła w życie 15 kwietnia 2016 r. Celem tych zmian ma być przyspieszenie i usprawnienie postępowania w zakresie znaków towarowych, jak również zachęcenie przedsiębiorców do sięgania po ochronę. Przedstawienie w publikacji zmienionej procedury funkcjonującej w polskim systemie udzielenia prawa ochronnego na znak towarowy zmierza - poprzez analizę dokonanych zmian - do próby odpowiedzi na pytanie, na czym one polegały, jaka jest ich istota, czy ich wprowadzenie jest rzeczywiście dla przedsiębiorców korzystne, jak również czy są oni - jako uprawnieni do praw wcześniejszych - na to przygotowani.

\section{Własność intelektualna a własność przemysłowa}

Pojęcie „własność intelektualna” zostało użyte po raz pierwszy w Konwencji o ustanowieniu Światowej Organizacji Intelektualnej, sporządzonej w Sztokholmie 14 lipca 1967 r. (tzw. Konwencja sztokholmska)².

Artykuł 2 tej konwencji zawiera definicje własności intelektualnej, określając, że pojęcie to oznacza prawa odnoszące się do:

- dzieł literackich,

- interpretacji artystów interpretatorów oraz do wykonań artystów wykonawców, do fonogramów i do programów radiowych i telewizyjnych,

- wynalazków we wszystkich dziedzinach działalności ludzkiej,

- wzorów przemysłowych,

- znaków towarowych i usługowych, także do nazw i oznaczeń handlowych,

- ochrony przed nieuczciwą konkurencją,

- wszelkich innych praw dotyczących działalności intelektualnej w dziedzinie przemysłowej, naukowej, literackiej i artystycznej.

Przez własność intelektualną należy więc rozumieć prawa majątkowe do dóbr niematerialnych o charakterze intelektualnym. Dobra te nie mają materialnej postaci, ale bardzo często można z nich skorzystać za pośrednictwem rzeczy. Prawa na dobrach niematerialnych, które powstają w wyniku działania ludzkiego, mają bezwzględny charakter³. Natomiast przedmioty

2 Dz. U. z 1975 r. Nr 9, poz. 49.

3 P. Podrecki, Środki ochrony praw własności intelektualnej, Warszawa 2010, s. 23 i 31 . 
materialne są dla dóbr niematerialnych pewnego rodzaju „nośnikami”, które umożliwiają ich poznanie i korzystanie z nich ${ }^{4}$. Są skuteczne erga omnes i oznaczają prawo do korzystania $z$ tych dóbr niematerialnych i korzystanie $\mathrm{z}$ nich w wyłączeniem osób trzecich.

Ustawodawstwo polskie nie zawiera legalnej definicji prawa własności intelektualnej, pojęcie to funkcjonuje przede wszystkim w języku prawniczym, jak również w doktrynie i orzecznictwie sądowym, które przyjmują znaczenie nadane mu przez międzynarodowe konwencje.

Należy zaznaczyć, że pojęcie własności intelektualnej zostało ujęte również w innym istotnym akcie prawa międzynarodowego - w Porozumieniu z dnia 15 kwietnia 1994 r. w sprawie handlowych aspektów praw własności intelektualnej (tzw. TRIPS) ${ }^{5}$, stanowiącym załącznik do Porozumienia z Marakeszu z dnia 15 kwietnia 1994 r. o ustanowieniu Światowej Organizacji Handlu (WTO).

Pojęcie własności przemysłowej jest pojęciem historycznie starszym. Po raz pierwszy zostało użyte w Konwencji paryskiej z dnia 20 marca 1883 r. o ochronie własności przemysłowej ${ }^{6}$. Od czasu wejścia w życie 7 lipca 1884 r. była ona kilkakrotnie zmieniana i rewidowana na konferencjach rewizyjnych (14 grudnia 1900 r. w Brukseli, 2 czerwca 1911 r. w Waszyngtonie, 6 listopada 1925 r. w Hadze, 2 czerwca 1934 r. w Londynie, 31 października 1958 r. w Lizbonie, 14 lipca 1967 r. w Sztokholmie). W wersji sztokholmskiej obok porozumienia TRIPS jest uznawana za najważniejszy akt prawa międzynarodowego w dziedzinie prawa własności przemysłowej $^{7}$. Jej sygnatariuszami obecnie jest 176 państw świata ${ }^{8}$.

Zgodnie $\mathrm{z}$ art. 1 ust. 2 Konwencji przedmiotem ochrony własności przemysłowej są:

- patenty na wynalazki,

- wzory użytkowe,

- wzory przemysłowe,

- znaki towarowe,

- znaki usługowe,

- nazwa handlowa,

- oznaczenia pochodzenia lub nazwy pochodzenia,

- zwalczanie nieuczciwej konkurencji.

Natomiast w myśl ust. 3 tego artykułu: „»Własność przemysłowa« rozumiana jest w najszerszym znaczeniu i stosuje się nie tylko do przemysłu

4 J. Kępiński [w:] System Prawa Handlowego, t. 3, Prawo własności przemysłowej, Warszawa 2015, s. 9.

5 Dz. U. z 1995 r. Nr 98, poz. 483 ze zm.

6 Dz. U. 1975, Nr 9, poz. 51 ze zm.

7 R. Skubisz, Podstawy prawa [w:] System Prawa Prywatnego, t. 14A, Prawo własności przemysłowej, R. Skubisz (red.), Warszawa 2012, s. 19.

8 Stan na 1 października 2016 r., dane ze strony internetowej http://www.wipo.int/ treaties/en/ShowResults.jsp?\&treaty_id=2. 
i handlu w ścisłym znaczeniu, ale również do przemysłów rolnych i wydobywczych oraz do wszystkich produktów wytworzonych lub naturalnych, jak na przykład: win, nasion, liści tytoniu, owoców, zwierząt, minerałów, wód mineralnych, piwa, kwiatów, mąki”. Podany w art. 1 ust. 2 Konwencji katalog dóbr własności przemysłowej jest katalogiem otwartym.

$\mathrm{W}$ polskim systemie prawnym własność przemysłową reguluje ustawa z dnia 30 czerwca 2000 r. - Prawo własności przemysłowej ${ }^{9}$.

Według tej ustawy własność przemysłowa obejmuje:

- wynalazki,

- wzory użytkowe,

- wzory przemysłowe,

- znaki towarowe,

- oznaczenia geograficzne,

- topografie układów scalonych.

W literaturze przedmiotu zwraca się uwagę, że Konwencja paryska zawiera definicję szerokiego pojęcia własności przemysłowej, gdyż nie ogranicza się tylko do przemysłu i handlu, lecz obejmuje także przemysł rolny i wydobywczy, a także produkty wytworzone i naturalne. Niezależnie od tego przeważa pogląd o konieczności traktowania własności intelektualnej jako pojęcia szerszego, nadrzędnego w stosunku do pojęcia własności przemysłowej, ponieważ swoim zakresem obejmuje prawa autorskie i prawa pokrewne, a także ochronę baz danych ${ }^{10}$.

\section{Decyzja Urzędu Patentowego}

Najważniejszym zdarzeniem prawnym przyznającym wyłączność korzystania z praw własności przemysłowej jest decyzja administracyjna. Organem uprawnionym do wydania takiego aktu jest Urząd Patentowym Rzeczypospolitej Polskiej, który jest centralnym organem administracji rządowej, właściwym w sprawach z zakresu własności przemysłowej i podlega Radzie Ministrów. Organ ten jest zaliczany do grupy organów quasi-sądowych, czyli do takiej kategorii organów rozstrzygających, które są powołane do orzekania, ale brakuje im niektórych cech sądu (np. niezależności), i które nie mają kompetencji do stosowania środków przymusu prawnego ${ }^{11}$. Wydana przez ten organ decyzja wywołuje skutek w postaci „przyporządkowania" danego dobra niematerialnego z zakresu własności przemysłowej konkretnemu uczestnikowi stosunków cywilnoprawnych ${ }^{12}$. W następstwie jej wydania następuje nabycie prawa (z patentu, praw ochronnych na zna-

9 Tekst jedn.: Dz. U. z 2017 r. poz. 776 ze zm., dalej p.w.p.

10 J. Kępiński [w:] System Prawa Handlowego..., s. 10-11.

11 J. Bodio, G. Borkowski, T. Demendecki, Ustrój organów ochrony prawnej. Część szczegółowa, Warszawa 2016, s. 23 i 155.

12 R. Skubisz, Podstawy prawa..., s. 65. 
ki towarowe i wzoru użytkowe, praw z rejestracji na wzory przemysłowe itp.), jednakże podkreślić należy, że jest to decyzja warunkowa, ponieważ konieczne jest uiszczenie opłaty za ochronę. W przeciwnym razie Urząd Patentowy wydaje decyzję o wygaśnięciu tego prawa.

Merytoryczną pracę Urzędu wykonują eksperci powoływani przez Prezesa UPRP, którzy wykonują następujące zadania:

- orzekają w sprawach o udzielenie patentów i dodatkowych praw ochronnych na wynalazki, praw ochronnych na wzory użytkowe oraz znaki towarowe, a także praw z rejestracji wzorów przemysłowych, oznaczeń geograficznych i topografii układów scalonych (samodzielnie, jednoosobowo, w zakresie orzekania podlegają wyłącznie ustawom - niezawisłość),

- orzekają w sprawach rozstrzyganych w postępowaniu spornym (kolegia orzekające do spraw spornych, w składzie trzech lub pięciu osób - tzw. sprawy zawiłe),

- reprezentują Urząd Patentowy RP w postępowaniu przed sądem administracyjnym w sprawach dotyczących rozpoznawania skarg na decyzje oraz postanowienia UPRP,

- realizują powierzone im dodatkowe funkcje (np. kierownicze).

Postępowanie przed Urzędem Patentowym RP jest szczególnym postępowaniem administracyjnym, toczącym się na podstawie przepisów ustawy - Prawo własności przemysłowej, a w zakresie nieuregulowanym tą ustawą - według przepisów ustawy z dnia 14 czerwca 1960 r. - Kodeks postępowania administracyjnego ${ }^{13}$. Kończy się wydaniem decyzji lub postanowienia.

\section{Charakterystyka systemów rejestracji znaków towarowych}

Warunkiem udzielenia ochrony na znak towarowy jest posiadanie przez niego zdolności rejestracyjnej. Zdolność ta oznacza, że w konkretnym przypadku nie występują względne i bezwzględne przeszkody udzielenia prawa ochronnego, a więc przyczyny dające podstawę do odmowy udzielenia takiej ochrony. Rozróżnienie podstaw odmowy rejestracji znaków towarowych na bezwzględne i względne opiera się na odmienności interesów, których ochronie służy dana przeszkoda rejestracji. Status bezwzględnych przypisuje się tym podstawom odmowy, które mają na uwadze interes publiczny, natomiast względnymi są pozostałe podstawy odmowy ustanawiane dla zabezpieczenie interesów indywidualnych. Ten materialnoprawny podział przeszkód rejestracji w kontekście znowelizowanych przepisów nabiera również znaczenia procesowego, ponieważ te dwie kategorie przeszkód podlegają badaniu w różnych trybach - systemach rejestracji znaków towarowych. Obecnie funkcjonują dwa takie systemy rejestracji znaków:

13 Tekst jedn.: Dz. U. z 2016 r. poz. 23 ze zm., dalej k.p.a. 
system badawczy i system rejestrowy. W systemie badawczym organ z urzędu przeprowadza badanie wszystkich przeszkód rejestracji, tj. przesłanek względnych i bezwzględnych. Procedura badawcza była korzystna dla właścicieli już zarejestrowanych znaków, ponieważ ekspert Urzędu niejako stał na ich straży. System ten obecnie obowiązuje w 10 krajach członkowskich, m.in. w Portugalii, Grecji i na Malcie. Z uwagi na długi czas oczekiwania na uzyskanie ochrony procedura ta zdecydowanie nie zaspokajała potrzeb przedsiębiorców, którzy na uzyskanie swojego prawa czekali zdecydowanie dłużej niż przewidziane prawem około dwanaście miesięcy. W nowym systemie sprzeciowowym organ przeprowadzi jedynie badanie formalnoprawne i sprawdzi wyłącznie bezwzględne przesłanki udzielenia ochrony (np. czy znaki nie są mylące lub sprzeczne $\mathrm{z}$ porządkiem publicznym). Oznacza to, że z urzędu nie będą kwestionowane znaki, które są identyczne lub podobne do znaków wcześniej zarejestrowanych. W systemie tym uprawnieni ze znaków wcześniejszych będą musieli sami zadbać o własne interesy i zgłosić sprzeciw na etapie postępowania zgłoszeniowego w celu niedopuszczenia do rejestracji identycznego lub podobnego znaku. W tym przypadku ekspert nie stoi już na straży praw przedsiębiorców - pełnoprawnych właścicieli praw ochronnych na swoje znaki towarowe.

W konsekwencji przejścia na system sprzeciowowy ustawodawca dokonał usystematyzowania wszystkich przesłanek odmowy udzielenia prawa ochronnego na znak towarowy. W art. $129^{1}$ p.w.p. wyszczególnione zostały enumeratywnie bezwzględne przesłanki odmowy udzielenia takiego prawa. Zgodnie z tym przepisem nie udziela się prawa ochronnego na oznaczenie, które:

1) nie może być znakiem towarowym;

2) nie nadaje się do odróżniania $\mathrm{w}$ obrocie towarów, dla których zostało zgłoszone;

3) składa się wyłącznie z elementów mogących służyć w obrocie do wskazania, w szczególności rodzaju towaru, jego pochodzenia, jakości, ilości, wartości, przeznaczenia, sposobu wytwarzania, składu, funkcji lub przydatności;

4) składa się wyłącznie z elementów, które weszły do języka potocznego lub są zwyczajowo używane w uczciwych i utrwalonych praktykach handlowych;

5) stanowi kształt towaru, który jest uwarunkowany wyłącznie jego naturą, jest niezbędny do uzyskania efektu technicznego lub zwiększa znacznie wartość towaru;

6) zostało zgłoszone w złej wierze;

7) jest sprzeczne z porządkiem publicznym lub dobrymi obyczajami;

8) zawiera element będący symbolem, w szczególności o charakterze religijnym, patriotycznym lub kulturowym, którego używanie obrażałoby uczucia religijne, patriotyczne lub tradycję narodową; 
9) zawiera symbol Rzeczypospolitej Polskiej (godło, barwy lub hymn), znak sił zbrojnych, organizacji paramilitarnej lub sił porządkowych, reprodukcję polskiego orderu, odznaczenia lub odznaki honorowej, odznaki lub oznaki wojskowej bądź innego oficjalnego lub powszechnie używanego odznaczenia i odznaki, w szczególności administracji rządowej lub samorządu terytorialnego albo organizacji społecznej działającej w ważnym interesie publicznym, gdy obszar działania tej organizacji obejmuje cały kraj lub znaczną jego część, jeżeli zgłaszający nie wykaże się uprawnieniem, w szczególności zezwoleniem właściwego organu państwa lub organu samorządu terytorialnego albo zgodą organizacji, na używanie oznaczenia w obrocie;

10) zawiera symbol (herb, flagę, godło) obcego państwa, nazwę, skrót nazwy bądź symbol (herb, flagę, godło) organizacji międzynarodowej lub przyjęte w obcym państwie urzędowe oznaczenie, stempel kontrolny lub gwarancyjny, jeżeli zakaz taki wynika z umów międzynarodowych, chyba że zgłaszający wykaże się zezwoleniem właściwego organu, które uprawnia go do używania takiego oznaczenia w obrocie;

11) zawiera urzędowo uznane oznaczenie przyjęte do stosowania w obrocie, w szczególności znak bezpieczeństwa, znak jakości lub cechę legalizacji, w zakresie, w jakim mogłoby to wprowadzić odbiorców w błąd co do charakteru takiego oznaczenia, o ile zgłaszający nie wykaże, że jest uprawniony do jego używania;

12) ze swojej istoty może wprowadzać odbiorców w błąd, w szczególności co do charakteru, jakości lub pochodzenia geograficznego towaru;

13) stanowi chronioną nazwę odmiany roślin i odnosi się do odmiany roślin tego samego lub pokrewnego gatunku.

W odniesieniu do wyrobów alkoholowych znak towarowy zawierający element geograficzny niezgodny z pochodzeniem wyrobu uważa się za znak wprowadzający odbiorców w błąd.

Nie udziela się prawa ochronnego na znak towarowy zawierający element geograficzny prawdziwy $\mathrm{w}$ sensie dosłownym co do terytorium, regionu lub miejsca, z którego towar pochodzi, który mógłby wprowadzić odbiorców w błąd, że towar pochodzi $\mathrm{z}$ innego, słynącego $\mathrm{z}$ danych wyrobów terenu. W przypadku homonimicznych oznaczeń geograficznych dla wina i piwa ochrona może być przyznana, z tym że Urząd Patentowy wezwie osobę, która dokonała zgłoszenia później, do dokonania w znaku odpowiednich zmian pozwalających na odróżnienie go od znaku wcześniejszego.

Nie udziela się prawa ochronnego na znak towarowy dla towarów identycznych lub podobnych, jeżeli znak ten jest identyczny lub podobny do zarejestrowanego oznaczenia geograficznego, nazwy pochodzenia, określenia tradycyjnego dla wina lub oznaczenia geograficznego napoju spirytusowego, których ochrona jest przewidziana na podstawie przepisów prawa i w zakresie w nich przewidzianym. 
Względne podstawy odmowy udzielenia prawa ochronnego na znak towarowy wymienione zostały $w$ art. $132^{1}$ p.w.p., a ich zaistnienie daje podstawę do złożenia sprzeciwu. Zatem w myśl tego przepisu, nie udziela się prawa ochronnego na znak jeżeli:

1) jego używanie narusza prawa osobiste lub majątkowe osób trzecich;

2) jest identyczny ze znakiem towarowym, na który udzielono prawa ochronnego z wcześniejszym pierwszeństwem na rzecz innej osoby dla identycznych towarów;

3) jest identyczny lub podobny do znaku towarowego, na który udzielono prawa ochronnego z wcześniejszym pierwszeństwem na rzecz innej osoby dla towarów identycznych lub podobnych, jeżeli zachodzi ryzyko wprowadzenia odbiorców w błąd, które obejmuje w szczególności ryzyko skojarzenia znaku zgłoszonego ze znakiem wcześniejszym;

4) jest identyczny lub podobny do renomowanego znaku towarowego, na który udzielono prawa ochronnego z wcześniejszym pierwszeństwem na rzecz innej osoby dla jakichkolwiek towarów, jeżeli używanie zgłoszonego znaku bez uzasadnionej przyczyny mogłoby przynieść zgłaszającemu nienależną korzyść lub być szkodliwe dla odróżniającego charakteru bądź renomy znaku wcześniejszego;

5) jest identyczny lub podobny do znaku towarowego, który przed datą, według której oznacza się pierwszeństwo do uzyskania prawa ochronnego, był w Rzeczypospolitej Polskiej powszechnie znany i używany jako znak towarowy przeznaczony do oznaczania towarów identycznych lub podobnych pochodzących od innej osoby, jeżeli zachodzi ryzyko wprowadzenia odbiorców w błąd, które obejmuje w szczególności ryzyko skojarzenia znaku zgłoszonego ze znakiem powszechnie znanym.

\section{Postępowanie w sprawie udzielenia prawa ochronnego na znak towarowy}

\subsection{Zgłoszenie znaku towarowego}

Postępowanie wszczynane jest wyłącznie na wniosek zgłaszającego, który jest stroną tego postępowania, a reprezentować go może rzecznik patentowy, jak również adwokat lub radca prawny - poza wyjątkami wskazanymi na wstępie opracowania). Nie ma tu zastosowania zasada wynikająca $z$ art. 28 k.p.a., zgodnie z którą stroną postępowania administracyjnego jest każdy, czyjego interesu prawnego lub obowiązku dotyczy postępowanie, albo kto żąda czynności organu ze względu na swój interes prawny lub obowiązek (interes prawny)

Procedura rozpoczyna się dokonaniem zgłoszenia znaku towarowego, które zawiera co najmniej oznaczenie zgłaszającego, oznaczenie będące przedmiotem zgłoszenia, a także towary i/lub usługi, dla których ten znak jest przeznaczony. Po nadaniu mu kolejnego numeru organ w pierwszym etapie dokonuje badania formalnego zmierzającego do potwierdzenia speł- 
nienia wszystkich ustawowych elementów zgłoszenia, w tym także wniesienie prawidłowej opłaty. Na tym etapie organ może wezwać zgłaszającego do uzupełnienia zgłoszenia lub usunięcia istotnych braków, wyznaczając stosowny termin do jego uzupełnienia, pod rygorem umorzenia postępowania.

Nie później niż w terminie dwóch miesięcy do daty zgłoszenia Urząd Patentowy dokonuje ujawnienia zgłoszenia - informacji o znaku w bazie zewnętrznej (stronie internetowej) Urzędu. Ujawnieniu podlegają następujące dane: informacje o znaku towarowy, dacie pierwszeństwa, dacie i numerze zgłoszenia, wykazie towarów i usług, imieniu i nazwisku lub nazwie zgłaszającego, jego miejscu zamieszkania lub siedzibie oraz kodzie kraju.

Kolejnym etapem postępowania Urzędu Patentowego jest badanie merytoryczne zgłoszenia, proceduralnie ograniczone jedynie do badania przesłanek bezwzględnych rejestracji znaku, określonych enumeratywnie w art. $129^{1}$ p.w.p. Ustawa nie precyzuje, jak długo ma trwać to badanie, wskazując jedynie, że niezwłocznie po jego zakończeniu Urząd dokonuje ogłoszenia w „Biuletynie Urzędu Patentowego” o zgłoszeniu znaku towarowego, co do którego nie stwierdzono braku warunków wymaganych do uzyskania prawa ochronnego na znak towarowy z przyczyn, o których mowa w art. $129^{1}$ ustawy. Równolegle sporządza on zawiadomienie o potencjalnie kolizyjnych znakach towarowych (np. zarejestrowanych już z wcześniejszym pierwszeństwem) i przekazuje je zgłaszającemu. Zawiadomienie to ma charakter tylko i wyłącznie informacyjny i nie wiąże ani organu, ani zgłaszającego. W ten sposób zgłaszający uzyska informację o potencjalnych przeszkodach z rejestracji wnikających z praw osób trzecich, nie gwarantuje to jednak, że te informacje zgłaszający uwzględni.

Publikacja w Biuletynie Urzędu Patentowego jest równoznaczna z ujawnieniem informacji o dokonaniu zgłoszenia. Warto podkreślić, że jeszcze $\mathrm{w}$ trakcie badania formalnoprawnego możliwe jest wydanie decyzji o odmowie udzielenia prawa ochronnego na znak towarowy, jeśli Urząd stwierdzi brak warunków wymaganych do uzyskania takiego prawa z przyczyn przewidzianych $\mathrm{w}$ art. $129^{1}$ p.w.p. Taka odmowa może dotyczyć całego znaku towarowego i towarów czy usług nim objętych, może być również wydana wtedy, kiedy przeszkoda ujawni się jedynie w stosunku tylko do niektórych towarów. Ważne, że taką decyzję organ może podjąć również po ogłoszeniu o zgłoszeniu znaku towarowego.

\subsection{Sprzeciw}

W terminie trzech miesięcy od daty ogłoszenia o zgłoszeniu znaku towarowego uprawniony do wcześniejszego znaku towarowego lub uprawniony z wcześniejszego prawa osobistego lub majątkowego może wnieść sprzeciw wobec zgłoszenia znaku towarowego z przyczyn stanowiących względne podstawy odmowy rejestracji takiego znaku. Termin ten liczy się od daty publikacji w Biuletynie Urzędu Patentowego i nie podlega przywróceniu. Sprzeciw inicjuje kolejny etap postępowania i wymaga uiszczenia opłaty. 
Po bezskutecznym upływie terminu do wniesienia sprzeciwu, jak również po ustaleniu braku istnienia bezwzględnych przesłanek uzasadniających odmowę udzielenia prawa ochronnego na znak towarowy Urząd Patentowy wydaję decyzję pozytywną, tj. udziela prawa ochronnego. Jest to decyzja warunkowa, uzależniona od uiszczenia przez zgłaszającego opłaty za dziesięcioletnią ochronę. W sytuacji niespełnienia tego warunku organ stwierdza wygaśnięcie decyzji, a zgłaszający nie uzyskuje prawa ochronnego.

Wniesiony we wskazanym przez ustawodawcę terminie sprzeciw powinien zawierać ustawowe elementy, jak oznaczenie stron, wskazanie podstawy faktycznej i prawnej wraz z uzasadnieniem i zakresem sprzeciwu oraz podpis wnoszącego sprzeciw. Precyzyjne wskazanie podstawy prawnej, jak i towarzyszące sprawie okoliczności faktyczne oraz jasne sformułowanie żądania w stosunku do spornego zgłoszenia jest bardzo istotne, ponieważ Urząd Patentowy rozpatruje sprzeciw tylko w jego granicach i jest związany podstawą prawną wskazaną przez wnoszącego sprzeciw. Brak formalny sprzeciwu w postaci niewskazania znaku towarowego, wobec którego sprzeciw jest wnoszony, może być uzupełniony jedynie w ustawowym terminie trzech miesięcy do jego wniesienia i nie może być przywrócony. W sytuacji wniesienia sprzeciwu po terminie lub zawierającego braki nieuzupełnione w terminie Urząd Patentowy wydaje postanowienie o pozostawieniu sprzeciwu bez rozpoznania, na które przysługuje środek zaskarżenia w postaci wniosku o ponowne rozpoznanie sprawy.

$\mathrm{W}$ ramach postępowania w sprawie sprzeciwu stronami są zgłaszający i wnoszący sprzeciw. Strony są poinformowane o możliwości ugodowego załatwienia sporu w terminie dwóch miesięcy od daty doręczenia informacji. W ramach tej ugody wprowadzono instytucję tzw. listów zgody, przewidzianą $\mathrm{w}$ art. 133 p.w.p. Zgodnie $\mathrm{z}$ nowym brzmieniem tego przepisu uprawniony do wcześniejszego znaku towarowego lub uprawniony z wcześniejszego prawa osobistego albo majątkowego może wyrazić zgodę na rejestrację kolizyjnego znaku towarowego. Zgoda taka dopuszcza do udzielenia prawa ochronnego na znak towarowy mimo kolizji z wcześniejszym prawem. Skuteczna jest tylko i wyłącznie zgoda wydana w formie pisemnej, powinna być bezwarunkowa i nie może być ograniczona żadnym terminem. Ustawa wprawdzie nie określa wymogów co do treści listu zgody, należy jednak przyjąć, że w liście tym powinien być wyraźnie określony znak towarowy, którego zgoda dotyczy, jak również należy powołać się na numer zgłoszenia, który został nadany przez Urząd Patentowy. Taki list zgody ma charakter wiążący dla Urzędu, co oznacza, że jest on zobowiązany do wydania decyzji o udzielenie prawa ochronnego na kolizyjny znak towarowy. Wiąże Urząd także w postępowaniach spornych wszczętych na skutek wniesienia sprzeciwu albo wniosku o unieważnienie.

Po upływie terminu wyznaczonego do ugodowego załatwienia sprawy Urząd Patentowy wzywa zgłaszającego do udzielenia odpowiedzi na sprzeciw w wyznaczonym terminie. $\mathrm{W}$ odpowiedzi na sprzeciw zgłaszający 
przedstawia zarzuty oraz przytacza wszystkie okoliczności faktyczne i dowody na ich poparcie. Organ przekazuje wnoszącemu sprzeciw odpowiedź na sprzeciw oraz wyznacza mu termin na zajęcie stanowiska i uzupełnienie dowodów. Ciężar dowodu w zakresie wykazania używania znaku towarowego lub istnienia ważnych powodów usprawiedliwiających nieużywanie znaku spoczywa na wnoszącym sprzeciw. Dalsza polemika jest dopuszczalna jedynie w terminach wyznaczonych przez Urząd.

Ustawa wprowadza swego rodzaju prekluzję dowodową, powodującą, że pomijane są twierdzenia i dowody niezgłoszone w wyznaczonym terminie, chyba że strona wykaże, że ich powołanie nie było możliwe, albo że potrzeba ich powołania wynikła później. Na etapie postępowania odwoławczego wskazanie nowych faktów i dowodów na ich potwierdzenie również jest znacznie utrudnione i jest dopuszczalne tylko wtedy, gdy ich powołanie wcześniej nie było możliwe lub potrzeba ich wskazania wynikła później.

Po rozpatrzeniu sprzeciwu Urząd Patentowy wydaje decyzję o oddaleniu sprzeciwu lub uznaniu go za zasadny w całości lub części. Od decyzji tej stronom służy środek zaskarżenia w postaci wniosku o ponowne rozpatrzenie sprawy, który jest rozstrzygany przez kolegia orzekające do spraw spornych (w składzie trzech ekspertów, a w tzw. sprawach zawiłych - pięciu). Wniosek wnoszony jest $\mathrm{w}$ terminie dwu miesięcy od daty doręczenia decyzji i wymaga uzasadnienia, a przed upływem terminu na jego wniesienie decyzja nie podlega wykonaniu. Rozprawa nie jest w postępowaniu odwoławczym obligatoryjną formą rozpoznania sprawy. Kolegium do spraw spornych Urzędu Patentowego przeprowadza rozprawę z urzędu lub na wniosek strony, jeżeli uzna to za zasadne. Kolegium rozstrzyga wniosek o ponowne rozpatrzenie sprawy poprzez wydanie decyzji administracyjnej, która może stanowić przedmiot skargi kierowanej do wojewódzkiego sądu administracyjnego.

Po prawomocnym zakończeniu wszystkich postępowań $\mathrm{w}$ sprawie sprzeciwu Urząd Patentowy odmawia udzielenia prawa ochronnego na znak towarowy w zakresie, w którym sprzeciwy zostały uznane za zasadne, a w pozostałym zakresie udziela prawa ochronnego na znak towarowy. Jak już wcześniej wspomniano, jest to decyzja warunkowa, której wejście do obrotu prawnego uzależnione jest od uiszczenia opłaty za dziesięcioletni okres ochrony. Decyzja ta również podlega zaskarżeniu na zasadach ogólnych.

\section{Podsumowanie}

Model postępowania o udzielenia prawa ochronnego na znak towarowy, ograniczający działania urzędu patentowego do badania jedynie przeszkód bezwzględnych, przeważa w większości państw Unii Europejskiej i jest praktykowany od niemal trzydziestu lat. Przez przedstawicieli nauki i praktyki jest uznawany za najbardziej efektywny i racjonalny. Polska była jednym z ostatnich krajów członkowskich, w którym obowiązywała procedura badawcza. 
Do korzyści wynikających ze zmian w procedurze zgłoszeniowej należy zaliczyć możliwość skrócenia procedury rejestracyjnej do około sześciu miesięcy (pod warunkiem niewniesienia sprzeciwu), możliwość modyfikacji znaku w trakcie jego rejestracji, w razie zakwestionowania przez Urząd pewnych elementów znaku możliwość zawarcia ugody między zgłaszającym a wnoszącym sprzeciw, jak również zniesienie wymogu interesu prawnego w postępowaniu o unieważnienie lub wygaszenie prawa ochronnego na znak towary.

Przez zwolenników wprowadzonych zmian nowe przepisy oceniane są pozytywnie z uwagi na możliwość jednak szybszej - z założenia i przy uzyskaniu odpowiednich warunków - ochrony, bo już po około sześciu miesiącach. Procedura sprzeciwowa daje większe szanse uzyskania ochrony, gdyż zmniejsza się ryzyko uzyskania odmowy z uwagi na niebadanie $\mathrm{z}$ urzędu przesłanek względnych uzasadniających odmowę udzielenia takiego prawa. Tym samym jednak niewątpliwie zwiększy się liczba postępowań spornych, jak również może nastąpić wzrost postępowań o unieważnienie prawa ochronnego, rozpoczynanych przez tych przedsiębiorców, którzy przeoczyli przysługujący im czas do zgłoszenia sprzeciwu.

Jednakże wprowadzenie tak istotnych zmian spowoduje znaczne obciążenie przedsiębiorców - właścicieli praw wcześniejszych kosztami swojej działalności z uwagi na konieczności stałego samodzielnego (lub przy pomocy profesjonalistów specjalizujących się w dziedzinie własności przemysłowej) monitorowania zgłoszeń, nie ograniczając się jedynie do monitoringu krajowego, ale także unijnego i światowego. Przedsiębiorcy będą musieli przyjąć do wiadomości, że Urząd Patentowy już nie stoi na straży ich praw i to oni sami muszą o nie zadbać.

Bibliografia

Bodio J., Borkowski G., Demendecki T., Ustrój organów ochrony prawnej. Część szczegółowa, Warszawa 2016.

Kępiński J. [w:] System Prawa Handlowego, t. 3, Prawo własności przemysłowej, Warszawa 2015.

Miklasiński Z., Prawo własności przemysłowej. Komentarz, Warszawa 2001.

Mordwiłko-Osajda J., Znak towarowy. Bezwzględne przeszkody rejestracji, Warszawa 2009.

Ochrona własności intelektualnej, A. Adamczak, M. du Vall (red.), Warszawa 2010.

Podrecki P., Środki ochrony praw własności intelektualnej, Warszawa 2010.

Skubisz R., Podstawy prawa [w:] System Prawa Prywatnego, t. 14A, Prawo własności przemysłowej, R. Skubisz (red.), Warszawa 2012.

Szczepanowska-Kozłowska K., Wyczerpanie praw własności przemysłowej. Patent i prawo ochronne na znak towarowy, Warszawa 2006.

System Prawa Handlowego, t. 3, Prawo własności przemysłowej, E. Nowińska, K. Szczepanowska-Kozłowska (red.), Warszawa 2015. 
Z dniem 15 kwietnia 2016 r. w polskim systemie rejestracji znaków towarowych, na skutek zmian wprowadzonych nowelizacją ustawy z dnia 30 czerwca 2000 r. - Prawo własności przemysłowej nastąpiła istotna zmiana w zakresie procedury udzielenia prawa ochronnego.

Przed nowelizacją obowiązywał tzw. system badawczy, który polegał na badaniu z urzędu wszystkich przeszkód rejestracji, tj. tzw. przesłanek względnych i bezwzględnych. Natomiast w systemie sprzeciwowym przeprowadzane jest jedynie badanie przesłanek bezwzględnych. Ten system ogranicza rolę Urzędu Patentowego w procesie rejestracji, zwiększając jednocześnie czujność i wymuszając konieczność większej aktywności podmiotów uprawnionych z praw wcześniejszych. Zmiana procedury na bardziej uproszczoną ma na celu skrócenie czasu rozpatrywania zgłoszeń, jak również dostosowanie przepisów krajowych do regulacji unijnych. Po zakończeniu postępowania w tym zakresie, które przeprowadzane jest przez eksperta, Urząd Patentowy może wydać decyzję o udzieleniu prawa ochronnego na znak towarowy lub o odmowie udzielenia takiego prawa ochronnego.

$\mathrm{W}$ artykule przedstawiono szczegółowo procedurę uzyskania prawa ochronnego na znak towarowy na podstawie obowiązujących obecnie, zmienionych przepisów ustawy - Prawo własności przemysłowej, ze wskazaniem, czego te zmiany dotyczyły.

Słowa kluczowe: znak towarowy, Urząd Patentowy, decyzja administracyjna, postępowanie administracyjne, przesłanki bezwzględne i względne

\section{Decisions of the Patent Office in the Trademark Protection Granting Procedure}

Abstract

As of 15 April 2016, a major change took place in the Polish trademark registration system concerning the procedure for granting trademark protective right as a result of the amendment of the Industrial Property Rights Act of 30 June 2000.

Prior to the amendment, the "examination" system was used, whereby all obstacles to registration, the so-called relative and absolute conditions, were examined ex officio. Under the now binding contrarian system, only absolute conditions are examined. The system limits the role of the Patent Office in the registration process while increasing alertness and necessitating more activity on the part of entities entitled under previously granted rights. The change of the procedure has been simplify in order to shorten the application examination duration as well as adjust domestic legislation to EU law. After the closing of the relevant procedure conducted by an expert, the Patent Office may issue a decision on granting or refusing to grant trademark protection right.

The article presents in detail the procedure for obtaining trademark protection right on the basis of the currently applicable amended provisions of the Industrial Property Rights Act, indicating the essence of the changes.

Keywords: trademark, Patent Office, administrative decision, administrative proceedings, absolute and relative conditions 